\title{
Trends in causes of maternal mortality in a tertiary care centre in Kerala, India
}

\author{
Sreekumari U., Shilpa Nair* \\ Department of Obstetrics and Gynecology, SATH, Government Medical College, Trivandrum, Kerala, India
}

Received: 13 September 2018

Accepted: 29 September 2018

\section{*Correspondence:}

Dr. Shilpa Nair,

E-mail: shilpasuni12003@yahoo.co.in

Copyright: $\odot$ the author(s), publisher and licensee Medip Academy. This is an open-access article distributed under the terms of the Creative Commons Attribution Non-Commercial License, which permits unrestricted non-commercial use, distribution, and reproduction in any medium, provided the original work is properly cited.

\begin{abstract}
Background: Kerala has the lowest maternal mortality ratio compared to other Indian states. But when compared to developed countries Kerala has still a long way to go. The present study aimed to analyse the causes of maternal deaths that occurred in the study setting for a period of seven years (2011-2017).

Methods: Retrospective study which was conducted at SAT hospital, Govt. Medical College, Thiruvananthapuram. All maternal deaths that occurred in the study setting from January 2011 to December 2017 were found out from registers. The baseline socio demographic characteristics, gravidity, parity, cause of death were recorded using structured proforma and analyzed using SPSS software.

Results: Total maternal deaths during the time period was 101. There were 66441 live births. Maternal mortality ratio for the seven-year period was 152 . Majority were primigravidae (50.49\%), of low socio-economic status (79.2\%), rural population $(81.1 \%)$ and referred from periphery after identifying complication $(85.1 \%)$. Caessarean section was the commonest mode of delivery among them (43.56\%). Regarding cause of death, indirect maternal deaths were more than direct deaths $(50.49 \%$ versus $42.57 \%)$. Cardiac disorder was the leading indirect cause $(12.87 \%)$, Postpartum hemorrhage (13.86\%), Hypertensive disorders (8.91\%) and Sepsis $(7.9 \%)$ were the leading direct causes.

Conclusions: Early referral protocols, increasing blood and blood component availability in the periphery should be reinforced. Regarding indirect causes medical boards should be constituted in tertiary care centres for prompt and efficient multidisciplinary care.
\end{abstract}

Keywords: Direct maternal deaths, Indirect maternal deaths, Maternal mortality

\section{INTRODUCTION}

Maternal mortality has long been seen as a primary indicator of quality of health care. The toll that unsafe mother hood takes on lives and health of women becomes really tragic as most of them are preventable by timely interventions. As rightly stated, for every woman who dies many more suffer from serious conditions (near misses). ${ }^{1}$ Maternal death is defined as death of women while pregnant or within 42 days of termination of pregnancy irrespective of duration or site of pregnancy from any cause related to or aggravated by pregnancy or its management but not by accidental or incidental causes (ICD 10). ${ }^{2}$ Maternal mortality ratio (maternal death/ 1 lakh live births) provides a measure of safe deliveries and efficiency of maternal care and allows international comparison.

Globally maternal mortality ratio has reduced by $44 \%$. Though impressive, this is less than half of the 5.5\% annual rate of reduction needed to achieve maternal mortality targeted for 2015 on MDG. Now building on momentum gathered by MDG 5, the sustainable goals establish a transformative new agenda for maternal health 
to reduce MMR to less than 70 by $2030 .{ }^{3}$ India has registered significant improvement in this aspect. MMR has come down from 167 in 2011-13 to 130 in 2014-16. Kerala has turned in a stellar performance which is evidence of robust public health system and high levels of education. MMR has reduced from 61 in 2011-13 to 46 in 2014-16.

However only few studies have been conducted in tertiary hospitals which bear the major burden of high risk and referral care and maternal deaths. Analysis conducted at tertiary set up in Gambia showed that despite the global declining trend in maternal mortality, in tertiary hospital it showed a rise. ${ }^{5}$ So, with this back ground authors decided to conduct a study on trends in maternal mortality and analyzing MMR in present institute which is one of the major tertiary care centres in Kerala, a state which stands apart in the field of maternal health.

\section{METHODS}

Clearance from institutional research committee and institutional ethics committee was obtained before starting the study. This was a retrospective observational study.

\section{Inclusion criteria}

- All patients either booked in present hospital or referred from Government or private sector hospitals and died in present hospital antenatally, intrapartum or postnatally within 42 days of termination of pregnancy either due to causes directly related to pregnancy, aggravated by pregnancy or unrelated to pregnancy were included as the study population.

- Those patients after admission who were transferred to critical care units or other departments like cardiology or nephrology for continued care and later died were also included in the study.

- The study subjects included those with either intrauterine or extra uterine pregnancy.

\section{Exclusion criteria}

- Those patients who died after 42 days of termination of pregnancy were excluded from the study.

- Those patients who nearly died but survived (near misses) were excluded from the study.

Maternal mortality cases as described in the inclusion criteria that occurred in present hospital for a seven-year period-from January 2011 to December 2017 were identified from hospital records. This include maternal mortality register maintained in this hospital where data of every year is recorded separately regarding baseline socio demographic details, referral status, condition at arrival, diagnosis, specialists involved, treatment and other surgical intervention given, blood and blood products used, ventilator and ICU facilities used etc wherever data was inadequate the corresponding case records were verified from medical records library. The institutional audit register was also verified for accuracy of diagnosis. The details of every year were recorded separately using same structured proforma. The total number of live births during every year from January 2011 to December 2017 was also collected from hospital statistics department. Maternal mortality ratio for every year was calculated separately and mean maternal mortality ratio for seven-year period was also calculated.

\section{Statistical analysis}

The information was entered in excel worksheet. The descriptive statistics were analyzed using SPSS software.

\section{RESULTS}

Total number of maternal deaths that occurred in the study setting during the study period of seven years (2011-2017) was 101. During this seven-year period there were 66441 live births. The maternal mortality ratio for the seven-year period was 152 per one lakh live births. Maternal mortality ratio was highest in 2013 (212/lakh) and lowest in 2016 (105/1 lakh) (Figure 1).

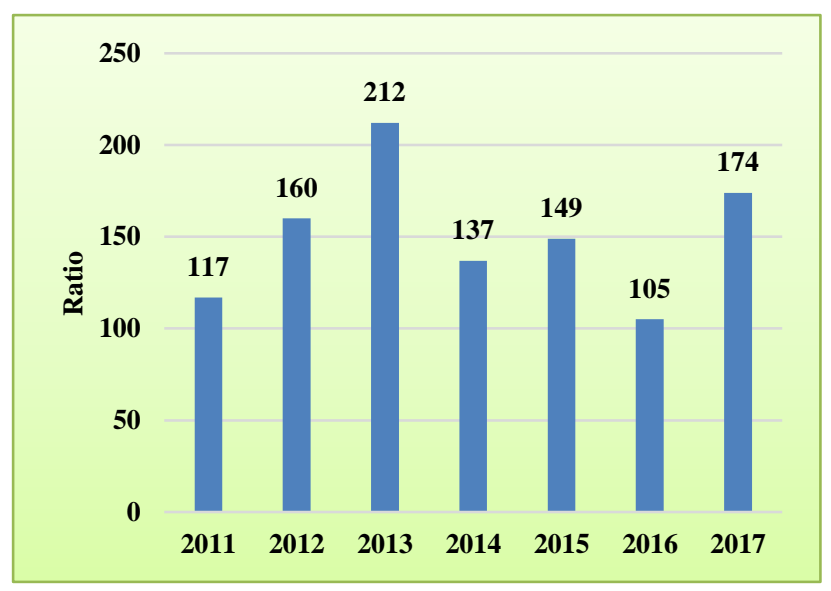

Figure 1: Maternal mortality ratio/ 1 lakh live births.

Among these 101 maternal deaths, majority $(n=31$, $30.6 \%$ ) belonged to 20-24 years age group. A significant proportion of deaths occurred in 30-34-year age group also $(n=28,27.7 \%)$. Less number of deaths occurred in extremes of age-ten (9.9\%) in less than 19 years age group and six $(5.9 \%)$ in more than 35 years age group. The youngest among these 101 cases was an eighteenyear-old who died of Dengue shock syndrome and oldest were two in numbers, forty years of age, one of them died due to sepsis and other due to postpartum hemorrhage. Regarding place of residence, majority belonged to rural areas $(n=82,81.1 \%)$. There were no un booked cases among the study group. But majority of the cases $(n=86$, $85.1 \%$ ) were referred from first referral units after identification of complication. Reasons for referral were need for multi-disciplinary team approach in case of medical complications, round the clock intensive 
monitoring, lack of adequate blood and blood components in case of obstetric hemorrhage. Socio economically, eighty among them $(79.2 \%)$ belong to low income group. Half among these $101 \quad(n=51,50.49 \%)$ were primi gravidae and $33(32.67 \%)$ were second gravidae. There was one fifth gravida $(0.9 \%)$ who had previous four abortions and there were no one more than gravida 5. Caesarean section was the commonest mode of delivery among them $(n=44,43.56 \%)$ and thirty-four $(33.66 \%)$ delivered through vaginal route. In eleven cases deaths occurred associated with abortions (10.89\%) and one death as a result of ruptured accessory horn pregnancy $(0.9 \%)$. Eleven cases expired undelivered $(10.89 \%)$ (Table 1).

Table 1: Base line socio demographic details.

\begin{tabular}{|c|c|c|c|}
\hline & Category & No. $(n=101)$ & $\%$ \\
\hline \multirow{5}{*}{ Age } & $<19$ & 10 & 9.9 \\
\hline & $20-24$ & 31 & 30.6 \\
\hline & $25-29$ & 26 & 25.7 \\
\hline & $30-34$ & 28 & 27.7 \\
\hline & $>35$ & 6 & 5.9 \\
\hline \multirow{2}{*}{ Residence } & Rural & 82 & 81.1 \\
\hline & Urban & 19 & 18.9 \\
\hline \multirow{2}{*}{$\begin{array}{l}\text { Socio economic } \\
\text { status }\end{array}$} & Low & 80 & 79.2 \\
\hline & Medium & 21 & 20.8 \\
\hline \multirow{3}{*}{ Registration status } & Referred & 86 & 85.1 \\
\hline & Booked & 15 & 14.9 \\
\hline & Un booked & 0 & 0 \\
\hline \multirow{5}{*}{ Gravidity } & Primigravida & 51 & 50.49 \\
\hline & Gravida 2 & 33 & 32.67 \\
\hline & Gravida 3 & 8 & 7.9 \\
\hline & Gravida 4 & 8 & 7.9 \\
\hline & Gravida 5 & 1 & 0.9 \\
\hline \multirow{5}{*}{ Mode of delivery } & Vaginal & 34 & 33.66 \\
\hline & Cesarean & 44 & 43.56 \\
\hline & Abortion & 11 & 10.89 \\
\hline & Ectopic & 1 & 0.9 \\
\hline & Undelivered & 11 & 10.89 \\
\hline
\end{tabular}

Among these eleven cases of abortions there were no illegal abortions. Two maternal deaths were due to septic abortion- one being a psychiatric patient presented in septic shock with foul smelling products of conception and in another, abortion occurred spontaneously while patient was having urinary tract infection followed by septicaemia. All other cases of abortions occurred in association with maternal systemic diseases. (Two cases of viral bronchopneumonia, one case of Guillen-Barre syndrome, one each with pyelonephrtis, encephalitis, viral myocarditis, suicide, HELLP, MTP with sterilization followed by haemoperitoneum and sepsis).

Those who died undelivered were due to acute maternal conditions, where death occurred within a short time (four cases of heart disease, two cases each of amniotic fluid embolism and suicide, one case each of meningo encephalitis, burns and snake bite).
Indirect maternal deaths accounted for a major proportion among the total 101 cases $(n=51,50.49 \%)$, while direct causes led to $43(42.57 \%)$ deaths. Seven $(6.9 \%)$ deaths occurred due to incidental causes. Cardiac disease was the leading systemic disease which took thirteen $(12.87 \%)$ lives, followed by respiratory diseases $(n=8$, $7.9 \%)$.

Table 2: Indirect maternal deaths: causes.

\begin{tabular}{|llll|}
\hline Cause & No. & $\begin{array}{l}\% \text { of indirect } \\
\text { deaths }(\mathrm{n}=51)\end{array}$ & $\begin{array}{l}\% \text { of total } \\
(\mathrm{n}=101)\end{array}$ \\
\hline Cardiac disease & 13 & 25.49 & 12.87 \\
\hline Respiratory failure & 8 & 15.68 & 7.9 \\
\hline Liver disease & 6 & 11.76 & 5.9 \\
\hline Maternal pyrexia & 7 & 13.72 & 6.9 \\
\hline Epilepsy & 6 & 11.76 & 5.9 \\
\hline Malignancy & 4 & 7.8 & 3.9 \\
\hline Intracranial bleed & 3 & 5.8 & 2.9 \\
\hline Renal disease & 2 & 3.9 & 1.9 \\
\hline $\begin{array}{l}\text { Cortical venous } \\
\text { thrombosis }\end{array}$ & 1 & 1.9 & 0.9 \\
\hline $\begin{array}{l}\text { Sepsis due to } \\
\text { cellulitis }\end{array}$ & 1 & 1.9 & 0.9 \\
\hline Total & 51 & & 50.49 \\
\hline
\end{tabular}

Coming to individual diseases among cardiovascular causes of mortality, there were five case each of cardio myopathies and rheumatic valvular diseases. Among rheumatic heart diseases three deaths were due to prosthetic valve dysfunction, one due to Eisenmenger and one death due to acute left ventricular failure due to severe mitral and tricuspid regurgitation. The rest three cases were one each of pulmonary atresia, Marfans with aortic root dilatation and acute myocardial infraction. Maternal pyrexia leading to death accounted for $6.9 \%$ of maternal deaths $(n=7)$, viral fever with myocarditis (three cases), dengue fever (two cases) and ARDS with saturation fall (two cases) were the killer diseases among maternal pyrexia. Different malignancies accounted for four $(3.9 \%)$ of maternal deaths (Table 2 ).

Table 3: Direct maternal deaths: causes.

\begin{tabular}{|llll|}
\hline Causes & No. & $\begin{array}{l}\text { \% of direct } \\
\text { deaths } \mathbf{N}=\mathbf{4 3}\end{array}$ & $\begin{array}{l}\text { \% of total } \\
\mathbf{N}=101\end{array}$ \\
\hline PPH & 14 & 32.55 & 13.86 \\
\hline $\begin{array}{l}\text { Hypertensive } \\
\text { disorders }\end{array}$ & 9 & 20.93 & 8.91 \\
\hline $\begin{array}{l}\text { Sepsis } \\
\text { Amniotic fluid } \\
\text { embolism }\end{array}$ & 8 & 18.6 & 7.9 \\
\hline $\begin{array}{l}\text { Pulmonary } \\
\text { embolism }\end{array}$ & 3 & 13.95 & 5.9 \\
\hline $\begin{array}{l}\text { Rupture uterus } \\
\text { Ruptured accessory }\end{array}$ & 1 & 2.3 & 2.9 \\
\hline horn pregnancy & 1 & 2.3 & 0.9 \\
\hline Pulmonaryoedema & 1 & 2.3 & 0.9 \\
\hline
\end{tabular}


Although in total indirect maternal deaths overshoots direct causes, a single initiating event which took the lives of maximum number of mothers in the present study was post-partum haemorrhage $(n=14,13.86 \%)$. The second leading cause for direct maternal deaths was hypertensive disorders $(\mathrm{n}=9,8.91 \%)$ followed by sepsis $(\mathrm{n}=8,7.9 \%)$. Amniotic fluid embolism claimed the lives of six $(5.9 \%)$ cases and pulmonary embolism was the cause in three cases $(2.9 \%)$ (Table 3$)$.

Among accidental or incidental cause three (2.9\%) were due to suicide, two due to accidental burns (1.9\%), one each due to the snake bite and road traffic accident. During the initial five years (2011-2015) direct maternal death was less than fifty percent of total deaths where as in 2016 and 2017, direct causes predominated.

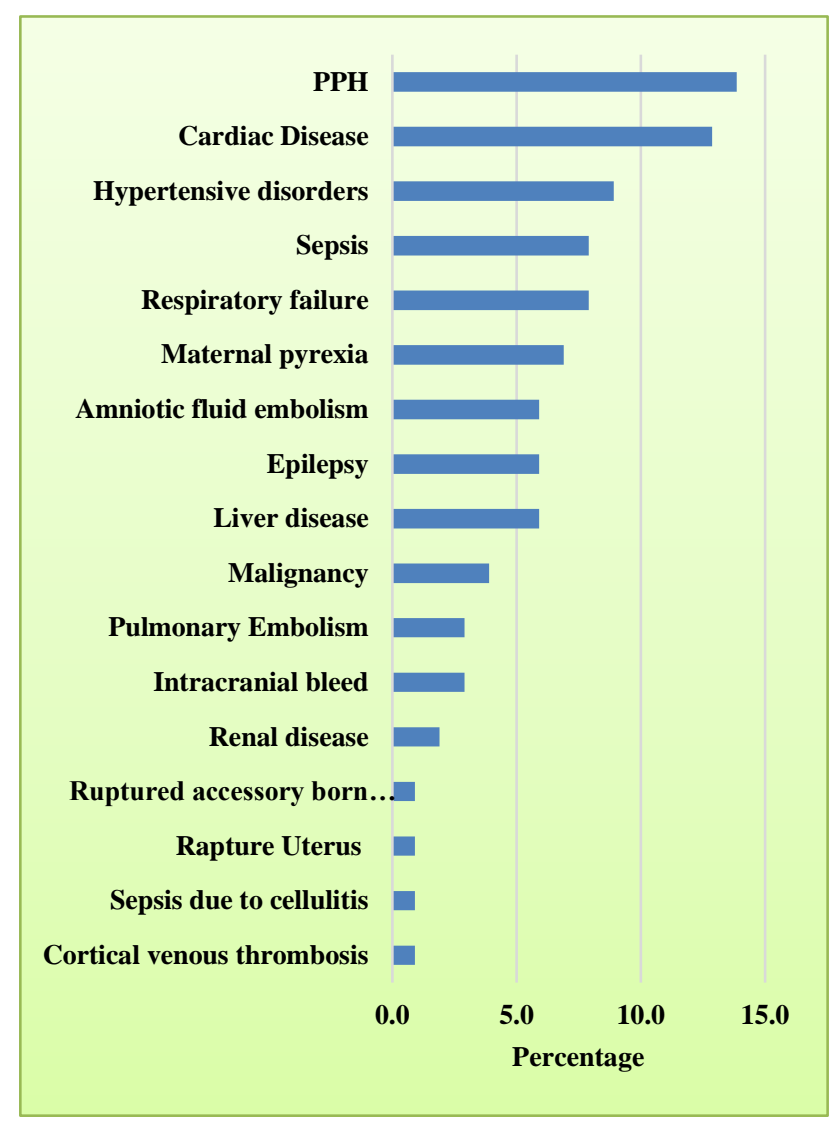

Figure 2: Causes of maternal mortality.

\section{DISCUSSION}

Maternal mortality ratio for the seven-year study period was 152/1 lakh. This agrees with MMR of Kozhikode (153) and that of India (130). 4,6 This is less than that reported from Selem, New Delhi and Bangladesh. ${ }^{7-9}$ This is much higher than that in developed nations and that of Kerala (46)., ${ }^{40}$ The higher rates of maternal mortality is because this is a tertiary care centre which caters patients from in and around $100 \mathrm{~km}$ which include the surrounding six districts. Studies from Gambia and West Maharashtra supports this observation. ${ }^{5,11}$ During the study period MMR does not show a steady fall. Paily VP et al has come up with the same observation stating that MMR of Kerala has remained static in the last couple of decades. ${ }^{12}$ Reduction in poverty and total fertility rate and improving female literacy shows statistically significant association with decline in MMR than merely increasing institutional deliveries alone. ${ }^{9,13}$ Quality of care is fundamental to improve maternal health outcomes. The effect of Janani Suraksha Yojana on MMR has been studied by Anirudha K Jain et al. He points out that the cash incentive may disproportionally attract pregnant women without complication to institution while the increased work load due to this leads to women with complication not getting proper treatment. ${ }^{14}$

Maximum number of maternal deaths occurred in 20-24year age group. Similar observation is seen in studies from Salem and Maharashtra, but studies conducted by Garg $\mathrm{P}$ et al and Khandale SN et al showed maximum deaths in 25-29 years age group. ${ }^{7,11,16,17}$ Mothers from rural areas and of low socio economic group succumbed to death more than that from urban areas in the present study which agrees with many other Indian studies. ${ }^{11,17-19}$ Majority of the cases $(85.1 \%)$ were referred from first referral units after identification of complications as observed also in Salem and Imphal. ${ }^{15,19}$ In the present study no illiterate or unbooked patient were there. This was a major difference from many other Indian studies where majority of maternal deaths were among un booked patients. ${ }^{8,11,16-19}$

There were no grand multi gravida among the maternal mortality group and primigravidae comprised more than half $(50.49 \%)$. Similar observation was seen from New Delhi. ${ }^{8}$ More deaths occurred among multi parous women in studies conducted by Murthy BK et al, Garg $\mathrm{P}$ et $\mathrm{al}^{17}$, Patel DM et al and Khamathem PD et al. ${ }^{11,16,18,20}$ Indirect causes predominated and amounted to $50.49 \%$ while direct causes accounted for $42.57 \%$ deaths. This is another major difference from studies conducted in other Indian states where in almost all studies direct causes constituted the major chunk. ${ }^{7,11,15-21}$

Although this can be counted as a progress towards attaining health standards of developed nations, authors still have the triad of hemorrhage, hypertensive disorders and sepsis in significant proportions and as leading direct causes. As far as direct causes are concerned, similar to what has been pointed out from one study from Bangladesh, they are still important contributing factors. ${ }^{9}$

\section{CONCLUSION}

In the present study leading cause of maternal deaths were indirect. Direct deaths constituted to less than $50 \%$, but further reduction in direct deaths is needed to attain western standards. Maybe we are in the right track, but further strengthening of peripheral hospitals with more blood and blood component storage facilities, better ICU care, providing round the clock specialists in anesthesia, 
critical care and cardiology is mandatory to achieve the level targeted by SDG.

\section{Funding: No funding sources}

Conflict of interest: None declared

Ethical approval: The study was approved by the Institutional Ethics Committee

\section{REFERENCES}

1. World Health Organization. Beyond the numbers: reviewing maternal deaths and complications to make pregnancy safer. Lewis G - British medical bulletin, 2003 - academic.oup.com. Available at: https://academic.oup.com/bmb/article/67/1/27/33038 3.

2. World Health Organization (WHO). International statistical classification of diseases and related health problems. 10th Revision. Volume 2. Instruction manual. 2010 ed. Geneva: WHO; 2011. Available at: www.who.int/classifications/icd/ICD10Volume2_en 2010.pdf.

3. WHO U. UNFPA, The World Bank and the United Nations Population Division. Trends in maternal mortality. 1990;2013:1-68. Available at: www.who.int/reproductivehealth/publications/monit oring/maternal-mortality.../en/.

4. Ramachandran P. Millennium development goals (MDG): India's progress and way forward to sustainable development goals. Proceedings of the Indian National Science Academy. 2016;82(5):135165 .

5. Idoko P, Anyanwu MO, Bass S. A retrospective analysis of trends in maternal mortality in a Gambian tertiary health centre. BMC Research Notes. 2017;10(1):493.

6. Chandran JR, Raj SV, Ramachandran A. Maternal near miss review from a tertiary care center in South India. Int J Reprod Contracept Obstet Gynecol. 2017;5(8):2657-60.

7. Sundari KM, Jayanthi RD, Ramasamy B. Trends in maternal mortality in a tertiary care hospital. Int $\mathrm{J}$ Reprod Contracept Obstet Gynecol. 2016;5(11):3659-62.

8. Mediratta G, Khullar H, Bhandari SK. An observational study of maternal mortality in a tertiary care hospital in New Delhi. J Indian Acad Clini Med. 2015;16(2).

9. El Arifeen S, Hill K, Ahsan KZ, Jamil K, Nahar Q, Streatfield PK. Maternal mortality in Bangladesh: a Countdown to 2015 country Khandale SN, Kedar K. Analysis of maternal mortality: a retrospective study at tertiary care centre. Lancet. 2014;384(9951):136674 .
10. Knight M, Tuffnell D, Kenyon S, Shakespeare J, Gray R, Kurinczuk JJ. Saving lives, improving mothers' care: Surveillance of maternal deaths in the UK 2011-13 and lessons learned to inform maternity care from the UK and Ireland. Confidential enquiries into maternal deaths and morbidity 2009-13. Available at: https://www.npeu.ox.ac.uk/mbrraceuk/reports.

11. Murthy BK, Murthy MB, Prabhu PM. Maternal mortality in a tertiary care hospital: a 10-year review. Int J Prevent Med. 2013;4(1):105.

12. Paily VP, Ambujam K, Rajasekharan Nair V, Thomas B. Confidential review of maternal deaths in Kerala: a country case study. BJOG: Int J Obstet Gynaecol. 2014;121:61-6.

13. Goli S, Jaleel AC. What is the cause of the decline in maternal mortality in India? Evidence from time series and cross-sectional analyses. J Biosoc Sci. 2014;46(3):351-65.

14. Jain AK. Janani Suraksha Yojana and the maternal mortality ratio. Eco Political Weekly. 2010;45(11):15-6.

15. Sundari KM, Priya RP. Maternal mortality: analysis of causes and preventable factors. Int $\mathrm{J}$ Reprod Contracept Obstet Gynecol. 2017;5(6):1719-21.

16. Garg P. To study maternal mortality and complications leading to maternal death in the tertiary care centre. Int $\mathrm{J}$ Med Res Rev. 2016;4(3):347-52.

17. Khandale SN, Kedar K. Analysis of maternal mortality: a retrospective study at tertiary care centre. Int J Reprod Contracept Obstet Gynecol. 2017;6(4):1610-3.

18. Patel DM, Patel MM, Salat VK. Two year review of maternal mortality at a tertiary care hospital of GMERS, Valsad, Gujarat, India. Int J Reprod Contracept Obstet Gynecol. 2018;7(6):2283-6.

19. Khumanthem PD, Chanam MS, Samjetshabam RD. Maternal mortality and its causes in a tertiary center. J Obstet Gynecol India. 2012;62(2):168-71.

20. Puri A, Yadav I, Jain N. Maternal mortality in an urban tertiary care hospital of North India. J Obstet Gynecol India. 2011;61(3):280.

21. Narlawar UW, Lilare RR, Nisal K. A comparative study on maternal mortality at government medical college, Nagpur. Indian J Appl Res. 2018;8(1).

Cite this article as: Sreekumari U, Nair S. Trends in causes of maternal mortality in a tertiary care centre in Kerala, India. Int J Reprod Contracept Obstet Gynecol 2018;7:4370-4. 